\title{
Artigo
}

\section{Dramaturgia e Ontologia nos Prolegômenos de Lukács}

\author{
Dramaturgie and Ontology in Lukács's Prolegomena
}

\author{
Cesar Kiraly \\ Professor de Estética e Teoria Política, Universidade Federal \\ Fluminense (UFF), Departamento de Ciência Política, \\ Niterói, RJ, Brasil \\ ckiraly@id.uff.br
}

Resumo: A proposta deste artigo é apresentar abordagem sobre os principais temas da obra de maturidade tardia de Lukács, o Prolegômenos para uma Ontologia Social. Para isso destacamos a reflexão sobre ontologia e dramaturgia social. A preocupação de Lukács é o ser social, deslocamo-la para a experiência política. De forma a perceber a ontologia política enquanto reflexão aberta a partir da inconsistência da dramaturgia, principalmente tal como pressuposta na ideia de representação política. Para tanto, o ceticismo é tematizado em problemas específicos.

Palavras-chave: Lukács; Ceticismo; Ontologia.

\begin{abstract}
I'm looking with this article to present the main themes of Lukács's last work, Prolegomena zur Ontologie des gesellschaftlichen Seins. For reach this objective I consider the reflexion on ontology and social dramaturgy. The main concern of Lukács is social ontology, but I change that to political experience. In a way to realize political ontology as a reflection opened by the inconsistency of the dramaturgy mainly as presupposed in the idea of political representation. For this, I need to talk about some problems coming from philosophical skepticism.
\end{abstract}

Keywords: Lukács; Skepticism; Ontology. 
"Aliás, seja qual for a situação, o povo é sempre senhor de mudar suas leis, mesmo as melhores, pois, se for de seu agrado fazer o mal a si mesmo, quem terá o direito de impedi-lo?" (ROUSSEAU, 1999). Com essas palavras, Rousseau encerra o segundo parágrafo, do capítulo XII, Do Contrato Social. Um pouco antes, nas três últimas frases, do penúltimo parágrafo do capítulo X, ele nos diz que parte da dificuldade da obra da legislação se deve ao fato de que essa precisa destruir, em certo sentido, mais do que estabelecer (ROUSSEAU, 1999, p. 125). Assim, deve a população destruir e nada possui o direito de impedi-la. Noutras palavras, ela se interrompe no momento em que o corpo destruidor se cansa. Quão mais o objeto resiste, mais rápido o corpo se cansa? A resposta seria afirmativa se o ímpeto fosse constante. Notemos, ele pode aumentar na mesma medida da resistência. Ora, aquilo que não deseja ser aniquilado, precisa saber se dar em holocausto, ou em holograma, se diante de um ímpeto que não se reinventa no obstáculo; e tornar-se uma parede de rochas se alvo de algo que se interrompe pela resistência. Como saber? Parece que o início da resistência é uma aposta a respeito da natureza do inimigo, e sendo esse produtor de ambivalência, também acerca do amigo; resiste, ou se entrega, esperando que o primeiro ato, se porventura errado, não desencadeie processo irreversível de devastação, justo, para que se possa, então, agir orientadamente, por reação. Todavia, o resultado da aposta bem feita, correta, por assim dizer, é a reafirmação dos contornos da imagem que defende; se o ânimo aumentava na resistência e se tem cessão, se o ímpeto buscava a cessão para crescer e encontra resistência. Se um povo é sempre senhor para mudar as suas leis, a resistência é sempre livre para fazer suas apostas, e como a dizimação é o que a aguarda, fazê-lo é necessário. A destruição parece valer para o que resiste, pois a quebra de um ânimo é a morte de uma certa expansão.

A aposta tem algo de incrivelmente moral, ela só pode ser julgada no plano enunciativo que a faz necessária. Não há como dizer errada a aposta em que não se estava para celebrar. No máximo se pode aprender com uma aposta passada, mas o próprio exercício da imaginação, de tentar optar diferente, sem estar na condição existencial de risco, resvala na imoralidade de se responsabilizar o perecido. Por outro lado, a vida política nos obriga a restarmos identificados com todos os apostadores, perecidos ou devastadores, pois teremos que escolher, fatidicamente, entre resistir ou transigir. Por certo que existe aposta bem ou mal sucedida, mas o tempo nos impõe algumas dificuldades, porque o apostador bem sucedido não pode ser visto no passado como apostador, e sim como 
devastador. Ainda que saibamos, de modo lógico, que toda vitória é baseada numa aposta acerca do perecimento ou resistência do oponente, e que a surpresa seria fatal para a imagem que se busca consolidar, um apostador vivo não passa de um vivo; nesse caso, a história é o acúmulo das derrotas, apenas elas perdem o domínio sobre os contornos de suas imagens, justamente porque estilhaçadas. Se pudéssemos diferenciar, diríamos que só há ética dos vencedores e moral dos derrotados. Pois apenas o primeiro pode se persuadir de que algo no mundo se move a seu favor. Apenas a condição ética permite que a culpa por se estar vivo seja atribuída à vida.

A dramaturgia surge então para ser uma disciplina da ilusão, para ser uma ciência dos ausentes. A ontologia da dramaturgia é a mesma da política, mas esta se revolve para esfumaçar aquela. Dramaturgia e Representação são as duas faces de uma moeda de uma moeda de um rosto só. A genealogia da representação dramatúrgica - para gastar uma expressão redundante - tem inscrição na teoria do conhecimento e boa parte da tinta é gasta para dizer que a representação da coisa em nosso espírito não é a coisa mesma. Isso, claramente, expande os limites do drama. Também para a alma foi especulada uma, por assim dizer, democracia indireta, segundo a qual o objeto pensado seria o senador (representante) de uma experiência povo (representado). Se o representante é aquele que fala pelo ausente, então temos a dramaturgia estabelecida, mesmo que seja mínima. Pode o objeto representado falar pela experiência, o ator falar pelo personagem, este pelo autor, o representante pelo representado, a igualdade pela liberdade? Não deveria, mas fala. Assim, a densidade dramatúrgica se deve a intensidade com que o mandato nos persuade. No caso da relação entre autor e personagem, o mandato é bastante intenso, inclusive, como nos lembra Deleuze, no caso dos personagens conceituais; em alguns ambientes de filia, o representante adquire autonomia com relação ao representado. Noutras, como no caso do sufrágio político, o vínculo parece tão tênue que parece arbitrário. Por essas razões, faz-se mister problematizar a dramaturgia.

II

\section{When the wind blows the water white and black}

\section{T.S. Eliot, The Love Song of J. Alfred Prufrock}

A estratégia assumida por Platão, para permanecer no embate político, de modo incidental, pelo menos, é bastante atraente, tanto quanto a tentativa de Aristóteles de tornar a política, pela catarse, mais afeita aos modos descritivos. Parece-nos que para a 
adesão à lógica entimêmica, e, por conseguinte, permitir que a vida política se oriente por algo que não seja apenas a vitória, pressupõe a prática catártica, para que os partícipes se tornem disponíveis a argumentos. A teoria da representação de Platão pressupõe que a verdade política esteja em algum lugar outro que não na política. A incidentalidade e as alegorias serviriam para evidenciar que é preciso desistir da política para tê-la virtuosa. O mesmo ocorre para Aristóteles: a catarse em sentido próprio, pública portanto, a lógica, a determinação dos sofismas etc. servem para minimizar o impacto retórico, para dar à descrição a oportunidade de orientar a política. Não é a superfície descrita que interessa, e sim tornar explícita certa natureza categorial supostamente escondida pelos discursos. O drama, para Platão, busca a reconquista do espaço público perdido, mas para Aristóteles serve para limpar a política dos afetos que não lhe dizem respeito, e tal vigília exercida pelo comedimento deve ser constante. Não é difícil perceber dois movimentos do drama, bem como, duas posições filosóficas coerentemente deles derivadas: (1) aproximação pelo drama e filósofo distante, até mesmo temeroso acerca dos perigos da vida política, todavia pretencioso acerca de influência e estabilização dos ânimos públicos pelo drama e (2) filósofo próximo e vigilante, para realizar a manutenção das condições de descritividade. O fato é que tanto a atitude pretenciosa, quanto aquela que, por não abandonar o convívio conflitivo, é mais comedida em suas prescrições, conhecem a política por ontologias que Ihe são estrangeiras. Há inadmissibilidade de componente autóctone à política, inultrapassável. É por isso que os juízos de Platão não descrevem e os de Aristóteles nela não incidem, pelo menos não por suas próprias cores.

A ontologia política, diriam alguns, vincula inclusive o que Platão e Aristóteles consideram o ontológico, na sua dinâmica universal, e, com mais razão, qualquer ontologia particular. O abandono da esfera política, visto da perspectiva da ontologia política, seria bastante arriscado, pois significaria deixar o mundo. O modo alegórico assumiria o risco de se afastar do mundo, para poder disputá-lo "de dentro", a partir da conquista de toda sensibilidade capaz de perceber o funcionamento da máquina incidental. Ele agarra-se a isso com unhas e dentes, certo que essa conquista poderia se reverter na evidência de que abandonar é o melhor, posto não ser necessário o vínculo entre verdade e disputa argumentativa. A prática descritiva, por outro lado, correria o risco de abandonar o mundo para disputá-lo "de fora", a partir do apego ao fato prudente e à narrativa estabilizada. O exaurimento descritivo dos fatos forneceria, 
de modo direto, participativo, a evidência de que habitar o público é o melhor, porque assim a universalidade daria seus contornos, desde o conflito harmonizado, de modo a mostrar a incidentalidade como uma forma de desistência frívola. A ontologia política, por sua vez, reconheceria que o incidental e o descritivo, as alegorias e as categorias, manejadas em seus extremos, apenas inventariam a disponibilidade para a essência, resolvida, para todos os efeitos, arbitrariamente. Isso quer dizer que o discurso do acesso à essência, por pretexto, interno e externo, é um dos derivados da experiência política, e não a sua razão. A incidentalidade e a descrição são duas poderosas ferramentas de confronto político e são melhor utilizadas a partir de um ponto de vista ontológico. Além disso, parece haver ponto de acordo entre a ontologia política e a moralidade, segundo o qual ver a primeira ajuda a incrementar positivamente a segunda. Por certo, a polaridade platônico-aristotélica é mencionada aqui de modo estratégico, menos preocupada com as especificidades que a cosmologia grega obriga aos pensamentos de tais autores, e mais com o fato de que o incidental e o descritivo, polarizados, são posições que se repetem quando ao infinito, e por isso a preferência por uma raiz. O moderno será invocado para esclarecer a ontologia política, posto que nos parece que ela deve ser compreendida em termos de crítica cética à dialética.

Um elemento clássico não pode ser esquecido: se a política possui ontologia, isso significa que ela pode ser encoberta. Se falávamos dos modos da dramaturgia, era justamente para tanto, são eles os encobridores. Como conciliar o fato de que há representação e ontologia política? Não seria a presença da ontologia antitética à da representação? Pois o certo seria, uma vez que deixamos para trás Platão e Aristóteles, nesse pontos específicos, dizer que há senão representação, apenas dramaturgia, e não ontologia. O fato é que não há ontologia, apenas representações; o princípio que as organiza é o que se denomina uma ontologia política. Se há ontologia, existe encobrimento, ora, pois, cabe à uma ciência da política remover o entulho restado sobre este princípio de organização. Nesse sentido é que não se pode tomar o "ôntico" pelos "silogismos analógicos precipitados, determinações que são totalmente estranhas a ele, apenas imaginadas por nós [...]". Na verdade, a ontologia política é o princípio de organização das sucessivas imagens políticas, um fio de associação entre idéias. Apesar de ser habitual tomar o acidente pelo princípio, trata-se de equivocidade cognitiva que reverbera em imoralidade. Então, onde começar a procurar a ontologia política? 
Na imediaticidade da vida cotidiana, naquilo que pode ser tomado como o instituído, em sua vivacidade espontânea, o momento "autêntico em si". Na variabilidade das aparências a se relacionarem por um padrão indiscutível, sempre vinculadas pela mesma contratura, que não existe antes delas, mas que, pela experiência, acaba por mostrar ser a lógica da política. Posto isso, é evidente perceber que a ontologia política demanda antecipação crítica, sem tal força moral é impossível fazer o olho caminhar na direção do "mais simples"1 (LUKÁCS, 2010, p. 37).

A crítica é a disciplina do desencobrimento do estratificado em direção à aparência e sua logicidade, tais podem ser tomados como o princípio recebedor do nome "ontologia política". A performance da ultrapassagem de Platão e Aristóteles é a mesma para Kant e Hegel e não precisa ser reencenada: ligar o em-si à política, abrandada em sua eloqüência, ou o espírito à incidentalidade, atendente por efeitos monumentais, é o que se espera. Da mesma forma a crítica não precisaria gastar muitos dos seus cartuchos com o indivíduo, pois é inaceitável não vê-lo como epifenômeno de algo bastante cristalizado, e que sua ruína se dá na primeira virada ontológica rumo à imediaticidade da experiência cotidiana.

Não há qualquer mistério ao dizermos que a alma é a soma dos acidentes, sem qualquer resto, é por isso que não há ontologia do indivíduo, mas tão somente da individuação, aceitando que esse termo diz a soma dos acidentes numa unidade aritmética. Por essa razão é que se pode dizer que uma ciência da política não se interessa por homens, muito embora suas reflexões possam ser fundamentais para a sua preservação, mas pela natureza humana. Se a alma é o conjunto dos acidentes - portanto não há que se falar em dualismo entre ela e o corpo -, ela pode ser dita como um outro nome ao que a natureza humana se refere: a unidade aritmética dos acidentes. Natureza humana é aquilo que se institui por acúmulo dos acidentes, a alma, ora, é a sua dimensão expressiva.

A experiência é contemporânea à natureza humana, mas não o é ao homem, que é uma derivação bastante distante. Se a ontologia política possui papel de determinação com relação às outras ontologias regionais, cabe perceber que ela interessa à experiência em sua imediaticidade. Assim, uma vez que são esgotadas as questões sobre a forma, o tempo etc. e passamos aos valores, damo-nos conta da falta de espaço ontológico

1 Se fosse o caso de chamar os elementos encobridores de ideologia, já seria sob a lógica da ideologia como saída da ideologia, o que não quer dizer outra coisa senão crença. Nesse sentido é que o ceticismo filosófico, nas figuras de Montaigne, Bayle e Hume, pode ser uma via de entrada arejada para reler a dialética. 
para a arbitrariedade antropológica, o mal e o bem são questões de segunda ordem. A experiência política não é a experiência toda, o que se torna límpido ao dizermos que nem toda experiência é política, mas é claro que toda experiência pode assumir contornos políticos. Existe algo como uma centelha política em todo átomo de experiência, por isso a experiência política determina as outras. Seria tolo dizermos que a experiência é nossa, seria igualmente insensato depender da imaginação para tê-la sem nós. A questão não é saber se os animais são cruéis, mas saber que o movimento de restrição, e de manutenção dessa, abarca-nos a todos, a crueldade não é o nome de um mal, pelo menos não inicialmente, mas de um movimento ontológico segundo o qual as fissuras vitais são identificadas por dores que precisam ser mantidas. Talvez o mais acertado fosse começar pelo geológico, mas imaginem a quimera que seria nos convencermos de uma geologia que fizesse sentido sem nós, ocuparíamos mais o nosso tempo com as especificidades do jogo pensado, do que com a ontologia traçada. Dessa forma, ainda que não careçamos de qualquer animismo, sabemos que a pedra está em relação de dependência com a ontologia política, apenas porque os efeitos do político são mineralizadores, e não porque a pedra possui valores. A ontologia pré-política julga que deveria traçar a causa do movimento, quando o caso era saber os determinismos. Não há rosto na pedra, mas não há pedra sem que um dos efeitos seja a natureza se poder mineral. Assim, podemos pensar a pedra sem termos de nos cansar com os estatutos de realização ou naturalismos, ora, não há pedra que não nos encontre. Nesse sentido é que não há pedra que não encontre a crueldade. Ainda que as fissuras nela feitas pelo mar ou vento não tenham que ver com sentir, elas encontram em nós um correlato chamado dor. A dor mantida é crueldade. Por isso, para além do ponto e das cores, ao tocarmos os valores, a organização ontológica assumirá sentido ao ser remetida à crueldade. Nós somos um ponto irreversível desde que somos encontrados. Assim o político a tudo determina² (LUKÁCS, 2010, p. 42).

Cabe, então, indagar pelo voluntário. Por quê? Porque a crueldade concerne a movimento restritivo a partir do qual uma fissura é imposta e mantida. Seria excessivamente permissivo aceitarmos a involuntariedade da restrição, a ela deve ser ligada alguma operação reflexiva, dentro da qual o político começa na vontade de instituir. Uma outra

2 "Só quando o homem primitivo começa a torturar seu prisioneiro de guerra é que surge - como produto causal do devir humano - a crueldade, como todas as suas conseqüências futuras, cada vez mais refinadas." 
maneira de entender esse problema seria remeter à consciência da atividade reflexiva nos momentos de deliberação, o que ligaria a política menos à ontologia e mais aos gregos, todavia muito dificilmente poderia nos ser objetado, o fato de que a reflexividade deliberativa decorre da reflexividade, pela inadmissibilidade daqueles que não deliberam, ou da diferença entre os que podem e os que não podem deliberar. Esta solução não desapropriaria completamente a autoridade grega sobre a política, mas diria que a política se inicia na dimensão anterior à reflexividade a partir da qual são apresentadas restrições para a viabilidade da vida. O porquê da restrição, que é o que caracteriza a reflexividade, é posterior à consciência de que é necessário restringir para prosseguir, isso quer dizer que a política se inicia com a crueldade, contudo a deliberação é o ato pelo qual deve ser contida. A política se inicia na liberdade de marcar para permanecer livre e a reflexividade surge para conter o aprofundamento do restritivo. A voluntariedade se caracteriza pela dor causada de modo consciente, mais do que isso, pela sua manutenção. A dor involuntária não é política, a dor voluntária não mantida, também não é política. A política se inaugura na restrição consciente que dura no tempo (LUKÁCS, 2010, p. 47).

\section{III}

Por que a reflexividade é relevante para a política? Não o é por causa ontológica, e sim por determinantes morais, seguidos ao vislumbramento ontológico. Além do que não é toda reflexividade seguida à restrição que é moralmente positiva. Pode ser o caso de afirmarmos que a crueldade inicia duas direções reflexivas: (1) encobridora da crueldade, por ignorância ou maldade e (3) desencobridora da restrição, para que essa se faça evidente. Da primeira se segue a religião, a moralidade abstrata e o discurso ético e da segunda a moralidade prática, em virtude ao vislumbramento ontológico³ (LUKÁCS, 2010, p. 48). A questão é que ver a crueldade, pelo menos em sua dimensão mais radical, em alguma medida, faz-nos insensíveis a ela, e tal poderia ser tomado como uma fratura ontológica: algo que somos, que não podemos ver, ainda que invisível não seja. Lukács

3 "Devido a projeções desse tipo, surge na ideologia esboçada pela religião uma segunda realidade, que encobre a verdadeira constituição do ser, assumindo em relação a ele a função de um ser mais legítimo e mais elevado, mas ao mesmo tempo, por longos períodos, a indispensável ideologia conserva um poder social, formando, assim, uma parte inseparável do respectivo ser social. Só quando essa prática, essa práxis social, o poder que influencia diretamente o ser social, se debilitou socialmente, puderam surgir os processos ideológicos de esclarecimento, que passaram a purificar o ser daquele acréscimos nascidos dele mesmo, mas que o distorciam." 
o diz em termos de "desantropomorfização", de que ela "[...] é e continuará sendo um dos mais importantes e indispensáveis meios para o conhecimento do ser como ele realmente é, como ele é em si, como foi e como permanece sendo" (LUKÁCS, 2010, p. 61). O ser tal como é, não é. Contudo, se nos perguntássemos pelo ser para a experiência política, teríamos como resposta que as coisas, tal como são, estão vinculadas à forma humana. Isso quer dizer que as coisas, tal como elas são, estão vinculadas, em âmbito político, a se poder suportar a entrevisão da crueldade, até aquele momento em que não há mais experiência política, porque a forma humana saiu de férias. A crueldade é o processo de desantropomorfização: ver tem que ver com ela: vê-la é não mais ver.

Aprender a ver a experiência é fazê-lo pelo processo de abstração, segundo o qual o mundo seria percebido - o mundo com pessoas - tal como se fosse independente das pessoas. Esse é um grande problema: descrever um estado de coisas humano, como se fosse independente da natureza humana, e isso já seria uma teoria da natureza humana. Antes de tudo é preciso saber que esse é um artifício anti-humanista, para que não estejamos sempre presos pelo horror, ou pelo embevecimento, que os nossos valores nos causam, pois quando essa brincadeira se torna realismo, é porque está chegando o tempo de parar. Isto posto é o caso de dizer que a história das representações é a que nos interessa. Não é o caso de buscarmos entre os gregos, ou fazê-lo por demais, em função de que a crueldade não está ali, ou se está, só aparece com muito anacronismo, e a representação, de direito, interrompe-se no movimento contido da forma escultórica, ainda que, de fato, das representações não possam se livrar, mesmo com o banimento dos poetas. Os passarinhos a bicar as uvas imitadas e não as de verdade, ou Apeles ser capaz, por acidente, de fazer a mímesis da espuma às narinas do cavalo, acrescentam pontos à physis e não ao conhecimento político em si. É a loucura antropomórfica que nos prepara a utilização do obstáculo. É como se pudéssemos dizer que é a loucura antropomórfica do trabalho que permite o passo para o abstrato da exploração, a guinada à interioridade, promovida pelos protestantes, como requisito para se ver o desnível entre classes ${ }^{4}$ (LUKÁCS, 2010, p. 61).

Precisamos convir que uma coisa é percorrer o caminho ao abstrato, e outra é ter que realizar o esforço de ficcionar um mundo em que não estamos, sendo isso já um

4 "Deixa, desse modo, seu lugar para os momentos realmente existentes em si, e capacita o ser humano a perceber o mundo como ele é em si, independente dele."' [...] precisamente a desantropomorfização é um momento de decisiva importância para a humanização do ser humano [...]". 
excesso de ficção. Na história das representações, temos a supremacia do pictórico com a invenção da perspectiva, do claro escuro etc., e uma vez estabelecida a loucura antropomórfica: o caminho à decomposição. O abandono do claro escuro por Manet, a extinção da perspectiva por Cézanne, e, consequentemente, o abstrato instituído por Malevich. A invenção do abstrato por Malevich tem importância máxima, pois com ele o abstrato é instituído pictoricamente e não mais geometricamente, não estamos mais no mundo de Descartes, mas no de Hume. Estranhamente nos distanciávamos da composição do mundo ao cedermos à dualidade entre forma geométrica e figuração, ao mesmo tempo, jamais estivemos tão próximos de nós mesmos, quanto diante do quadrado negro sobre fundo branco, diante do pictórico que nos dotou da capacidade de compor objetos. Sempre pensamos pictoricamente, mesmo quando ainda não sabíamos compreender a nossa prática dessa forma. Desde sempre nossa prática foi pictórica, ainda que a ela déssemos cores de espírito. O nosso pensar sempre foi matéria bem como o nosso fazer, ainda quando resolvíamos cindir entre idéia e materialidade. O que foi necessário para que nos víssemos como somos, materialmente pictóricos? Foi necessário que um acidente colocasse o abstrato, fraturado talvez, diante dos nossos olhos, para que fosse conscientemente por nós produzido.

Por outro lado, ainda estamos aprisionados ao espaço do experimento, ainda percebemos o fazer pictórico adstrito à tela. A compreensão dotada de elementos de explicação do instituído pelo pictórico. Como eles foram parar lá? Na história, na cristalização das crenças, isso ainda nos é misterioso. Sabemos o que fizemos, todavia sem controlar como. De Duve bem nos demonstra esse processo. A chegada se dá com o ready made de Marcel Duchamp, mas o ponto de saída é a interrogação do aprisionamento do pensamento pictórico à tela, como se a pictorialidade não fosse a experiência mesma, e a elaboração de um nominalismo pictórico ${ }^{5}$ (DUVE, 1984, p. 27 , 128, 131). Uma vez promovida a passagem à cognição, diríamos que nos faltava que fosse demonstrado o modo pelo qual a relação entre sentido e nome se imbricava nos objetos, de tal forma a termos duas instâncias materiais, aquela física e a do nome. Sim, é um urinol, mas também uma obra de arte. Trata-se de uma demonstração em dois tempos, primeiro: urinol e depois: urinol como obra de arte, mostra-se na frente dos

5 "Por mais incerto que seja o pacto pelo qual a pintura é nomeada, a existência do nome prova a existência do pacto." [... .]. "Portanto, a aposta do modernismo não é nem a do gosto, nem a da teoria, mas a do nome." 
olhos, algo que nos pareceria misterioso e arbitrário, caso nos fosse dito. Em outros fenômenos, mostrar que a matéria do nome e a da física são imbricadas pode ser bem opaco, o fato é que o pictórico é a via da indiscernibilidade entre a matéria e o seu nome.

Tudo isso nos leva a crer que a via do abstrato na experiência não tem limites. Ela se inicia com o desenvolvimento da figuração (não é estranho que certa história da arte conte a história do olho), desenvolve-se com a redutio dos truques da mímesis, assume maturidade com o abstrato e demonstra sua dinâmica instituinte com o ready made. A ilimitação é o sublime da capacidade destrutiva e construtiva da fabricação de mundos. Carecemos de limites morais a serem encaminhados à experiência especializada que nos interessa, a da política. Dizemos que a política é uma experiência especializada, porque ela não concerne à vida toda, nem tudo é política, ainda que ela possa estar em qualquer lugar. Ela concerne às experiências restritivas produzidas pela dor, na verdade, aos eventos em que há provocação de uma dor contínua, de modo deliberado. Não é difícil nos darmos conta da tensão entre a experiência e a experiência política, tornar homólogas as duas é completamente inaceitável, o que mais nos impede de fazê-lo é a moralidade. Não sem ironia, o signo dessa liberdade é um urinol e a passagem demonstrativa seja a de se tornar obra de arte, por assim dizer, o não tão nobre, tornando-se distinto. A idéia de que Andy Warhol fez o mesmo com a lata de sopa e com a caixa de sabão em pó não dissolve a ironia, apenas a aprofunda à abissalidade da reprodutibilidade vulgar, de modo ainda mais perturbador que o urinol. A experiência, por sua pictorialidade, permite o acréscimo e a supressão de objetos, sem grande dificuldade, ainda mais com o auxílio das máquinas. Todavia, a supressão e o acréscimo de objetos na política devem ser compreendidos cum grano sallis.

\section{IV}

O ceticismo é sempre minoritário (descrença de causas sociológicas com ele não se confunde), mas, inconscientemente, o vocabulário pictórico é hegemônico. A colocação dos problemas em termos de perspectiva, cenário, atores (na elaboração dramatúrgica do pictórico), preto e branco, preto no branco, cores, novas cores, primeiro e segundo planos, pontos de fuga, nitidez, embaçamento, opacidade, transparência, ponto, traço etc. não é apenas uma liberalidade metafórica, e sim a literalidade de um modo de 
imaginar que se nos tornou natural, e que nos foi ensinado pela pintura, nela descoberto por acidente. Sim, a predominância absoluta deste modo de dizer, que expressa um olho outro, deve-se à revolução abstrata.

Tomamos consciência da habitação do abstrato entre nós, no momento em que nos é demonstrado que qualquer objeto é objeto pictórico, e que por isso pode transitar pelas circunstâncias, se assim ventarem as estratégias. Isso quer dizer que o vocabulário pictórico, torna-se predominante na linguagem comum, até mesmo hegemônico, a fazer com que fosse desabitado o vocabulário espiritual, deixando-o relegado, no campo da ciência, às antropologia e sociologia. Nada mais justo para uma ciência de contenção da crueldade do que buscar uma epistemologia que compreenda a natureza pictórica da linguagem. Pode-se perceber que essa linguagem, quando depurada, compõe o mundo em bases construtivistas: nela os objetos são postos em termos de adição e subtração, apenas o desenvolvimento esclarecido da pictorialidade na linguagem permite operá-la em termos de composição. Ora, as conseqüências morais de uma tal linguagem pictórica e objetal, que coloca os problemas em termos de adição e subtração, podem ser desastrosas. A pictorialidade da linguagem nos dá algo de bom e de ruim, ela nos dá elementos para nos esquivarmos de boa parte das bobagens do espírito, mas parece nos induzir a acreditar que a alma pública se compõe deliberativamente. Sugiro que a política se adiante e costure uma concepção de alma à bainha do plano pictórico, de modo a que ela surja como transparência sobre a entrevisão de qualquer objeto. A morte do espírito nos obriga à compreensão da história como representação e sistemas de crenças, e, benditamente, reforça o fato de que a alma individuada é a soma de nossos acidentes, nada mais belo do que isso; muito embora, em âmbito público, seja preciso optar por um objeto transparente, que dote a moralidade da plasticidade desta nova existência sem sentido implícito, para que este objeto posto, Zielsetzungen, realize seus efeitos de desocultamento da crueldade.

Mas que objeto posto transparente seria esse? Digo que é a forma humana, trata-se do mínimo humanismo suportável, não um humanismo do homem, mas da natureza humana, das formas, e não da expressão dos maus sentimentos. A forma humana deve ser atribuída sem custos, sem troca, sem barganha, atribuída também aos animais, relevos, o que for, melhor que seja expansiva do que mesquinha. Trata-se da antítese da economia de atribuição da forma humana apenas aos animais domésticos, a forma 
humana deve ser o nosso esforço inicial e o mais bem distribuídos dos valores, um comunismo, que se realiza pelo cerzimento da alma às barras da experiência. Que se veja um rosto na montanha? Façamos da sua destruição um homicídio. Percebe-se que a gratuidade da forma humana não se confunde com o antropomorfismo, não se trata de admitir a transcendência e nela ver o nosso rosto, no que está no alto, ver-se maior, por se ver no que se inventa, mesmo nas invenções mais servis; nem mesmo um animismo qualquer, por fazer transcender um objeto qualquer. Se quisermos, a gratuidade da forma humana pode ser compreendida como um animismo especial, pois consiste em ver o nosso rosto num objeto que não fala, tomado em seus próprios termos, sem divindade, que não transcende, sem homem; as coisas como elas são.

Aqui o cético vê uma ontologia materialista. Se para mais não fosse, apenas com ela pode fazer uma crítica apropriada da dramaturgia, ou, tão somente, a descrever. Trata-se de uma perspectiva. O primeiro passo, para uma ontologia materialista, é recusar a suposta distinção entre o pensamento e a experiência, ou entre idéia e objeto. Lukács supôs que poderia atingi-lo pela dialética na natureza, não pôde, ela apenas remete ao invisível, ao tempo infinito, ao misterioso momento em que experiência, pensamento, idéia e objeto se reuniriam. Isto é falso. A distinção, tomada como evidente, para daí promover o reencontro, é que é enganosa. A homologia está aí desde sempre. Qual foi a dificuldade que não pôde ser vencida por Lukács, muito embora tenha chegado mais próximo de resolvê-la que Hegel? Ele não foi capaz de encontrar conexões lógicas que ligassem a experiência mais ordinária à idéia mais complexa. Não pôde encontrar o vínculo de natureza entre a impressão mais simples, a idéia mais complexa e a crença estável. Não foi capaz de ligá-las, por um bom motivo, pelo fato de serem imagens. Esta é uma verdadeira ontologia: a da imagem. Por ela sabemos a continuidade entre experiência e pensamento, e a materialidade de ambos. A impressão é uma imagem mais intensa, inegociável em seus termos, a idéia é menos intensa, mais plástica, passível de ser construída no seu remetimento próximo, ou distante, a uma impressão, e a crença é uma imagem com a intensidade de uma impressão, com a plasticidade de uma idéia. A crença é sem dúvida o estado mais elaborado da matéria sobre a qual agimos, não é evidente o modo pelo qual concilia a inegociabilidade da impressão e o construtivismo da idéia. Sabemos, contudo, que a resposta está na temporalidade da história. A matéria histórica é matéria, não se distingue da experiência ou do pensamento, longe disso, 
reafirma a homologia; a plasticidade da crença é percebida apenas quando olhamos largos períodos históricos, e, mais ainda, somente a partir do oferecimento especulativo, quão mais perto o fenômeno, mais intensa é a especulação que força o aparecimento da plasticidade; com relação a eventos distantes, a intensidade especulativa pode ser minorada, se tivermos uma larga oferta de representações correlatas, i.e. fragmentos de evento.

Tudo isso serve para dizer que o apelo, ao mesmo tempo ontológico e imagista, melhor ainda, imagista, porque ontológico, muda a ênfase da vida: o contraste deve ser aplicado sobre a vida comum. Não há percepção ontológica que não seja imagem. "[R]econduzir o pensamento do mundo para o ser [...]" depende do reconhecimento que o ser é imagem, em todos os seus nexos lógicos. Podemos ignorar a imagem em quase todas as situações, mas não podemos fazê-lo na vida comum. "A vida cotidiana, em contrapartida - até devido a sua imediaticidade -, não pode em absoluto tornar-se consciente sem a permanente referência ao ser"6 (LUKÁCS, 2010, p. 69, 71). Se levarmos a cotidianidade a sério, teremos que admitir que a imagem se torna evidente em todos os movimentos incomuns que a povoam. Vários são os momentos em que a expectativa de um movimento é frustrada, sendo-o, a antianatomia apresenta uma fratura da imagem, se antes não era percebida, porque sadia em sua perfeição, sem arestas no tempo, o erro, o acidente, a dobra, a quebra, levando imperfeição e rugosidade, pequenas no hábito, entregam a imagem. É atributo da imagem restar lisa e nos persuadir de que talvez haja algo atrás de si própria, como uma canto da sereia; por outro lado, a atenção detida sobre o cotidiano, resistente ao doce aconchego da transcendência, à essa mesma música, nota as fissuras no plano, os acidentes, as antianatomias, o grotesco, o brutal, os estilhaçamentos, a desfiguração etc. Nesses momentos de fissura, em que nos é dado perguntar, 'o que é isso?', temos como resposta: - É uma imagem, posto estar quebrada. Trata-se de uma imagem quebrada. O mesmo ocorre para o som, quando corriqueiro, melódico, harmônico, dá-se como dotado de essência, basta que se prenda os ouvidos ao cotidiano para tê-lo, sobretudo, rítmico, imagético, ruidoso, dissonante,

6 " [U]ma ontologia que realmente queira apreender o ser precisa ver nestes fatos mais rudimentares e elementares do ser um ponto de partida importante para as análises. [...] [P]oderemos [...] observar que existem fenômenos do ser - muitas vezes bem importantes - que exatamente aqui, em seu primeiro e mais primitivo surgimento, mostram seu verdadeiro caráter ontológico [...]." [...]." Parte do fato de que o ser social, como adaptação ativa do homem ao seu ambiente, repousa primária e irrevogavelmente na práxis. Todas as características reais relevantes desse ser podem, portanto, ser compreendidas apenas a partir do exame ontológico das premissas [...]." 
serial etc., portanto, um ponto sobre a experiência: o som em suas quebras, mostra-se imagem. A consciência da imagem é a consciência do ser. No fim, a cotidianidade é uma preparação ontológica, aprender a olhar para as sombras e os reflexos, para começar a entender as imagens. É necessário dizer, ainda, que o objeto maduro da ontologia é a composição da imagem.

\section{V}

Se a ontologia se interrompesse na imagem, se assim procedesse o ceticismo, não seria mais do que uma ontologia crítica. Ele deseja falar também a partir do lugar que conquistou, fazê-lo em uma plataforma enunciativa, até o momento de desfazê-la, deseja estabelecer uma fala da composição, intenciona a enunciação como crítica ontológica. A ontologia crítica chega até a experiência e desenvolve mecanismos para ver a imagem, o modo natural pelo qual a atinge, dá-se redobrando a atenção sobre a cotidianidade, resistindo a fazer religião ou sociologia, e nisso guarda o resultado da exposição às descontinuidades, aos acidentes. A ontologia crítica apenas chega à fala a partir do cotidiano visto como imagem, descrito cada vez mais pela composição, é uma crítica ontológica, por isso a atividade eminentemente plástica da intervenção sobre os conflitos. A crítica de Marx seria verdadeiramente ontológica se tivesse sido capaz de ver a cotidianidade inteira no instante da fratura, se apercebesse, na descontinuidade, como imagem e composição, i.e. imagem dialética e não mais dialética da imagem.

O rosto humano só pode ser conhecido em nuances se tivermos o excesso da perspectiva abstrata. É com o quadrado negro que pudemos nos ver de um modo eficiente no que concerne à atividade (des)construtiva da imaginação. É certo também que a política pode ultrapassar o rosto, mas não deve. A política está - porque deve estar - amarrada à figurabilidade do rosto humano, portanto, à certa ordem figurativa, ainda que, bem-vindamente, embebida com abstração e ceticismo. Por essa razão, a imagem se movimenta de um lado à generidade - Gattungsmässigkeit - não-mais-muda e de outro ao calado-mutismo. Nem todo ente chega a falar, mas é bom saber que todos podem, se ligarmos a fala à expressão; todavia, é fato que existe uma forte ação de mutismo da política sobre a natureza humana. Assim a moralidade age: observa, por suas disciplinas de conhecimento, o caminho para o mutismo, embebendo seus enunciados 
de conferimento de fala. Lukács diz que a generidade é a"[...] qualidade objetiva elementar de cada ente"(LUKÁCS, 2010, p. 74). A tarefa moral da política, enquanto epistemologia, é descrever os processos de silenciamento. Posto que a atribuição do rosto humano deve ser gratuita, existe imoralidade no processo de cauterização do rosto, o que leva ao estado da condição muda-calada, e virtude, na coisa posta não-mais-muda.

O mutismo, em seu processo, diz respeito a singularidade poder, num momento, reverberar em individualidade, e noutro, em individuação. No primeiro caso, o que se tem é apenas uma imitação da coisa posta não-mais-muda, parece com ela, mas se está diante de um autômato. No segundo, trata-se especificamente da aquisição de voz, da verdadeira manifestação, da efetiva expressão. A individualidade é político-jurídica, consiste em um gênero, uma forma vazia que pode ser preenchida somente por entes mudos no exercício da mudez. Por esse motivo, Lukács vê uma "[...] paulatina transformação da singularidade em individualidade [...]" como tendência de desenvolvimento dos entes genéricos (LUKÁCS, 2010, p. 80). Assim, podemos dizer que a singularidade é a experiência nela mesma, podendo ser definida como aquilo que não se repete, que é o mesmo que dizer que a repetição é diferencial, a experiência se repete enquanto experiência, mas é sempre singular, de tal forma que as paixões da natureza humana podem ser reconhecidas como rebatimentos esperados. Isso quer dizer que a paixão é singular em nós. O processo de repetição não precisa reverberar em generidade, ainda que seja muito comum. Ela se inicia na prática cognitiva de percepção da repetição, em seu ponto comum com o novo acontecimento, de tal forma que o elemento diferencial se torne opaco e a identidade possa ser afirmada. A identidade não é o início, ele é a singularidade na diferença, ela é o meio do caminho, a partir do qual se abre a bifurcação entre generidade-muda e a não-mais-muda. Parece-nos que a individualidade é o aprofundamento do mutismo, um que não é dotado de expressão, que apenas reverbera comandos. Se fizéssemos justiça à individualidade, diríamos que ela é a melhor forma de ligar um ente mudo a outro inativo, porque seria paradoxal ligar o espaço vazio a um ente passional, na medida em que este precisa se fazer forma para se tornar detentor de vazio.

O vazio da individualidade se opõe ao preenchimento da individuação, logo, não precisa ser romantizado. Ele se mostra na imagem de uma sala vazia e silenciosa - não habitada, apenas por seu poder de não habitação continuada - e é fundamentalmente 
uma estrutura protetiva que tende ao exagero e à expansão. Há que se perguntar sobre: do que é feita? O que mantém a individualidade? Qual a estrutura de suas paredes? Há política nisso? A individualidade tem a crueldade como parede, a saber, a manutenção deliberada de uma dor por significativo espaço de tempo; há inexorabilidade nela, não haveria autoria sem ela, todavia, sob sua égide a inventividade é impedida, doce paradoxo, a inventividade se perde sem o que a impede - há que se reconhecer, na morte da autoria, a possibilidade da invenção, mas não a sua permanência -, por essa razão é justa a crítica de Lukács (2010, p. 91). A idéia de atribuir a genialidade à individualidade é um equívoco, pois o fato é que a invenção se torna tão somente perceptível, registrável, pode ser, por intermédio da estrutura oferecida pela individualização, de nenhuma forma a invenção espera o indivíduo para acontecer. Julgar que a individualização é a melhor forma de fotografar o autêntico implica em ignorar boa parte do rio que passa debaixo dessa ponte. Lukács não vê o tema da individuação, em todo o seu espectro, digamos assim, mas a sua percepção de que a individualidade não monopoliza o singular, com certeza serve de preâmbulo. A individuação é a correta fotografia conceitual do singular, ela é o duplo organizado da impressão, nas circunstâncias em que já se pode elaborar um discurso a partir da interioridade, ao percebê-la de fora. A individuação é tão indeterminada quanto a impressão. Ao ter uma variabilidade comedida, uma vez que individuar é se guardar no bolso como um punhado de areia, pode ser reconhecida. Não haveria alguma analogia entre a individualização e a individuação? A distinção, na verdade, deriva do lugar do qual se fala, e se torna clara quando percebemos que esse lugar é tornado vazio, no caso da individualidade, e é preenchido, no caso da individuação. Nesta se ouvem vozes múltiplas, e naquela uma única solitária. O encantamento solitário com a própria voz é estrito da individualidade e não da individuação. Esta desliza onde aquela é agorafóbica. Na individualidade há todo o processo de disciplina e controle social para que o individuado caiba em sapatos feitos sob números industriais. A individualização não é para ser vivida, e sim para fazer uma suposta vida funcionar, e sob esse pretexto, como nos sugere Lukács, torna-a menor do que si mesma.

\footnotetext{
7 "Foi costume muito difundido (que existe ainda hoje) ver na individualidade uma forma originária fundamental, por assim dizer antropológica, do ser do homem. Correto nisso é apenas que o ser humano em geral tem a possibilidade interna, nas reações a seu mundo exterior social [...], adequar-se ou rebelar-se praticamente contra as tendências objetivas de desenvolvimento, e, portanto à também àquelas da diferenciação das decisões alternativas. Sabemos, porém, que em última análise se trata apenas de uma possibilidade, da mobilização de uma reserva inferior até ali pouco ou nada utilizada. A história social registra muitos exemplos não somente de pessoas singulares, mas também de grupos inteiros, de estratos etc. [....".
} 
Nessa confrontação, o homem singular em uma tal sociedade é levado a transformar essa situação objetiva do ponto de vista do 'O que Fazer?' dentro de sua própria conduta de vida em uma questão que, muitas vezes, tem de responder prática e teoricamente segundo seus interesses e capacidades de vida, em certo ponto com risco de sucumbir. (LUKÁCS, 2010, p. 117).

Parece justo apontar que o marxismo de Lukács e o ceticismo estão muito próximos na pretensão ontológica de afirmar que a individualidade não representa um papel determinante nos fundamentos da vida social, ainda que o ceticismo o faça como um purgativo (LUKÁCS, 2010, p. 117). Entretanto, a pluralidade de vozes admitida pelo cético é muito mais expressiva do que a do marxista, que, de vez em quando, pode ser mais tolerante do que a de muitos dogmáticos. Por admitir o ruído, o cético se concentra, mesmo estando imerso na multidão - aceita os desafios da individuação -, enquanto que o dogmático, para se concentrar, precisa do silêncio do quarto vazio, de propriedade do indivíduo. O marxista se contenta com o gabinete. Ora, ele crítica a individualidade, mas não sabe falar sem ela. Cabe ao cético a demonstração performática da individualidade como acidente, não necessário, da individuação. É evidente que a individualidade venceu, e que a pressuposição de indivíduo humano abstrato e isolado é dela decorrente, mas a saída do marxismo, que agora analisamos, concerne em afirmar a finalidade como a casa da individuação, entretanto, apenas uma casa virtual, porque no dia a dia, na circunstância, parece nos fazer crer, é preciso se dobrar ao indivíduo. O ceticismo aposta ainda no contrapé.

Metodologicamente, importa que o marxismo não rejeita apenas, do ponto de vista ontológico geral, a pretensão ontológica de que a individualidade tenha uma originalidade e um papel determinante nos fundamentos da vida social, mas comprova que só uma fase particular do processo de desenvolvimento da humanidade pode produzir esse desenvolvimento da singularidade para a individualidade, que, portanto, esta última é resultado específico do processo transformado do conjunto dos fundamentos da humanidade, portanto, um produto particular do processo como um todo, nele fundado e em nenhuma circunstância uma forma do ser que pudesse fundar ontologicamente a sociabilidade. (LUKÁCS, 2010, p. 121).

Neste trecho destacado, o nosso ponto se faz explícito. Lukács admite a especificidade do indivíduo, mas apenas concebe como escapar dele no processo histórico, na finalidade. A título de poder se livrar de toda a individualidade, admite, politicamente pelo menos, a nela não tocar no momento presente, deixando-a, por assim dizer, governada por seu 
próprio desígnio. Assim a crítica afia os dentes na história, mas só morde o que não aparece. Cabe que a crítica deve ser feita de modo a arrancar pedaços do indivíduo no cotidiano, de modo a perceber a si própria como um adorno da individuação, dizemos, como começo; dessa forma, sempre que a individualidade perturba a individuação aquela deve ser politicamente combatida para ser deixada de lado. Não basta a visada da ontologia social, é preciso que o 'O que Fazer?' seja respondido com elementos de ontologia política. Ou melhor, que se faça claro que toda ontologia é política, ainda que se possa vê-la circunstancialmente como social. Não basta descrever a suposta finalidade, mas afirmar a atualidade dos movimentos cerceadores, e, nos derivativos da ação política, decorrentes de toda investigação, estabelecer os modos pelos quais a crueldade será contida. Ontológico é o processo geral da crueldade, é moral acompanhá-lo, para isso serve a epistemologia, e o pensamento político cuida para, desde o mapeamento, instituir a reversão atual desta tendência. Não parece ser crível o poder do pensamento em transformar a crueldade em outra coisa, isso não significa que seja tolerável vê-la escondida no indivíduo, sem nada dizer. Se tomarmos a fórmula "um ser objetivo é um não-ser", de modo a interpretá-la, de maneira não teleológica, chegamos à conclusão de que a sociabilidade, para prosseguir, nega a crueldade: (1) em seu próprio curso, (2) na manutenção de seu menor esforço e (3) no aprofundamento da crueldade. Isso sugere que sem o aspecto crítico do pensamento dedicado à ontologia política, o singular tenderia a ser soterrado pela individualidade. É exigível, nessa medida, que interna à uma imagem dialética, a crítica se oponha a negação social da crueldade, de modo a oferecer uma província para a invenção. De que forma a crítica à crueldade pode se posicionar com relação ao fato de que o próprio processo de nomeação é cruel? Aceitando a inexorabilidade de saída e a contendo socialmente ao seu mínimo.

\section{VI}

\section{INTERVIEWER: Some people say they can't understand your writing, even after they have read it two or three times. What approach would you suggest for them? FAULKNER: Read it four times}

Não podemos nos tranquilizar e abandonar o martírio, enquanto não tivermos notado o componente de crueldade na linguagem. Mesmo que o contexto percebido não seja cético, é certo que é característica da tradição cética perceber as referências em 
circunstâncias não tão explícitas, além de tomar conceitos de ambiente dogmático e reformá-los. Ora, o cético não pertence ao ceticismo, como o dogmático ao dogmatismo, da mesma forma o cético não adere a um sistema de pensamento, como um leitor comum - quando o kantiano está aderido ao sistema de Kant deve respeitar as premissas deste, sob pena de ser deixado só, ainda que o sistema surja de uma investigação, aderir a um sistema tem algo de doutrinário -, isso quer dizer que o ceticismo não é uma escola, mas um movimento. O dogmático, também abrangendo o pensador de escola, por aderir a premissas, desfruta e oferece uma facilidade, ele pode antecipar enunciados e tê-los antecipados, a partir do sistema ou da doutrina, dinâmica da qual o cético não pode se servir. Este não pode antecipar enunciados, pois não tem um sistema ou uma doutrina, além do que não pode ter os seus próprios enunciados antepostos, porque não reconhece premissas, somente circunstâncias, o enunciado cético é, a rigor, completamente novo. Ele não pode ser previsto, a única coisa que pode ser adivinhado é o movimento que o cético realiza, este é sempre o mesmo. Exato, o cético é imprevisível, o dogmático é antecipável, e onde o cético é imprevisível, que é no seu movimento, o dogmático é imprevisível. Qual é o movimento previsível do cético? Além da particular referência ao passado, este, necessariamente, para pensar: (1) toma a pluralidade como um fato lógico, (2) do qual decorre a equivalência dos enunciados (3) e a necessidade da visitação do mais estranho.

O cético não pode ter o enunciado antecipado, mas para falar percorrerá sempre um mesmo caminho, passante pelos três pontos referidos. Estes lugares são percorridos imaginativamente - e, por vezes, no caso dos céticos viajantes, fisicamente - toda vez em que se vai pensar. A questão é que o primeiro item impõe a espera da variedade, talvez maior do que a encontrada, e o terceiro determina que se continue buscando o que não se pode encontrar, posto saber o cético que o primeiro ponto é apenas um lugar. A diferença entre uma premissa e um lugar é que este não pode ser tomado em tons de verdadeiro ou falso. Assim, penso que devemos tomar a linguagem em termos de escritura, sendo o caso de trazermos a concepção física da linguagem para dentro do ceticismo, porque faz falta, além de oferecer coerência ao fato do conceito poder ser um lugar. O contrário de tomar a linguagem como escritura seria tomá-la precipuamente fala e submeter a escrita à posição de subalternidade e o pensamento à ordem etérea. A escritura vincula a enunciação à ordem dos traços físicos, empíricos e interpeláveis, enquanto que o privilégio 
da enunciação sobre a escritura libera o pensamento para delirar o transcendente, suposto. Se colocarmos a escritura e a língua falada face à face à distinção entre céticos e dogmáticos, teremos que existe uma forte afinidade da escritura com o ceticismo e da fala com o dogmatismo. Isso porque a fala pressupõe a relação não inscrita do sujeito com a sua razão, um vínculo mediato, de tal forma que a enunciação é um duplo da razão, e a escrita apenas a sua cópia precária. É claro que o cético não pode admiti-lo. A razão pensa a partir da experiência, uma vez que esta por si mesma é produtora de marcas, de uma escritura a ser lida pelo intelecto. Na verdade, a enunciação deriva de tais marcas da experiência no mundo, de tal escritura. Por isso, parece que o cético se aproxima dessa teoria para a linguagem, uma vez que não obsta a natureza escritural da experiência e a precedência dessa sobre a voz e a performance. O dogmático, sob pretexto de estar ligado à razão, resta aderido apenas a si mesmo e a suas convicções, suas premissas e seu movimento imprevisível, enquanto o cético, por estar ligado à experiência, e seu aspecto escritural, está ligado, conscientemente, ao que o ultrapassa, a previsibilidade do movimento, às convicções prováveis e à precariedade das premissas. O resultado da filantropia cética é ser inventivo na enunciação e não no movimento.

O dogmático, ao sair para a vida comum, incomodado com algum barulho, para pedir silêncio, leva o gabinete consigo e vê o mundo pela lente que a tudo organiza, porque só vê o que quer. O cético, ao se fechar no gabinete, traz o mundo consigo. Por essa razão é que a enunciação cética é pautada pela multiplicidade. É como se o cético concebesse que a experiência é feita de marcas e por isso é preciso trazer o sangue para o texto. A clareza enunciativa só é adquirida no contexto dogmático de previsibilidade dos enunciados, a limpidez é um efeito do compartilhamento das premissas. Apenas o dogmatismo é claro, se há dificuldade inicial, em alguns casos, ela se dissolve no momento em que se adere ao sistema. De uma outra perspectiva, podemos dizer que o dogmatismo se esquiva das interrupções próprias à experiência, por esse motivo não hesita. Se pensamos na experiência, então apesar de claro, o dogmático é profundamente obscuro. O cético não faz sistema, por esse motivo a sua escrita é sempre escura. Se um cético é claro é porque foi lido de modo apressado. Nesse sentido é que Montaigne diz que muitas falsidades e mentiras podem derivar de "uma frase clara, pura e perfeita"8 (MONTAIGNE, 1972, p. 208). Se o cético é habitante das aparências

8 Apologia de Raymond Sebond. 
é porque a obscuridade e a indistinção são características da experiência, e lhe parece obtuso tentar corrigir essa dinâmica, uma tola falsificação, por assim dizer. Se tomamos, todavia, a evidência da interrupção nas hesitações, e isso como clareza, então o cético é claro como céu de brigadeiro.

Isso põe os filósofos da escola de Pirro na impossibilidade de empregar a nossa maneira de falar para exprimirem a dúvida que, em tudo, constitui sua regra. Precisariam de outra língua; a nossa, inteiramente formada de afirmações, opõe-se à sua doutrina, de sorte que quando dizem: "duvido" poderíamos objetar que incorrem em contradição, pois afirmam que sabem que duvidam. Assim, para evitar semelhante objeção, tiveram de tomar de empréstimo à medicina uma comparação sem a qual não explicariam seu pensamento. Ao dizerem "eu ignoro", ou "eu duvido", acrescentam que ambas as proposições desaparecem com o resto da frase, assim como o ruibarbo expele os humores e com estes a si mesmo. Tal estado de espírito enuncia-se interrogativamente de maneira mais segura, dizendo-se "Que sei eu?"E é a minha divisa. Ea acompanho de uma balança. (MONTAIGNE, 1972, p. 248).

É a filantropia da leitura cética que permite ler Platão como um cético, Platão com um ensaísta, ainda que não seja, pois o ceticismo percebe que falar pela boca de muitas pessoas, tal como nos diálogos, ou como faz Lukács em seus escritos de juventude, tomar o diálogo como um ensaio, é, ou pode ser tomado, como um modo da sutileza, da diversidade e da pluralidade. Ora, não é ceticismo se não realiza o movimento sobre o qual falamos, mas o cético empresta a forma dubitativa ou a suspensão do juízo àquilo que decide abrigar, em o fazendo, transfigura as afirmações em investigações. A escada de mão pode servir como imagem para a prática do cético - por ela se sobe, e depois se a abandona -, se pararmos para refletir um pouco mais sobre isso, seremos instados a aceitar o não desaparecimento da escada e a previsibilidade da surpresa por parte daqueles que por ela sobem; não demoraria muito para que a escada deitada fora começasse a ser utilizada como premissa e não como indutora de certo movimento. Para a metáfora poder ser bem empregada é preciso que a escada seja consumida pelo fogo, que desapareça. Um cético, a bem da verdade, parece-nos agora, não deve aceitar uma escada pronta, mas o movimento imposto para a resolução da altura: (1) sempre haverá o que subir, (2) os modos, de alguma forma, se equivalem e (3) é preciso manter-se apegado ao estranho, para não fazer a forma de subir suplantar a subida. O ruibarbo é excelente para demonstrar o princípio, tanto quanto o mestre que abandona, no tempo certo, os discípulos - levantar a si próprio pelos cabelos -; apenas o cético prevê a 
dissolução dos possíveis paradoxos da performance. O próprio "eu duvido" é dissolvido pelo movimento realizado pelo cético, de modo que não se pode encontrar o "eu" que duvida, apenas a sociabilidade da dúvida.

O que diferencia o enigma cético, a possível obscuridade (ou clareza) da sua ação, daquele do dogmático? Podemos dizer que é a retribuição. O dogmático se vale do escuro como busca para a adesão à premissas e retribui o discípulo com o domínio de uma língua capaz de resolver os problemas que ela mesma criou. $O$ enigma cético não retribui: nem com a facilidade para compreender futuros enunciados e nem absolve da necessidade de invenção de uma voz outra. A título de estabilizar o movimento, o ceticismo insiste em manter o pensamento vivo. A clareza desiste do pensamento. Ela pode se dar pelo desejo de conquistar o leitor pelo abandono das hesitações. Dogmáticos e céticos, autênticos na enunciação, falam escuro: com a diferença de que o dogmático entende a premissa como uma candeia para o entendimento, quando, na verdade, ela nada mais é do que uma sujeição do pensamento. Montaigne diz, na Apologia, que os pirrônicos levam vantagem nas discussões, porque a vitória e a derrota, para eles, significam o mesmo. A lógica do embate condiciona o que pode ser dito. Se um dogmático prevalece é porque abdica de seus princípios para vencer, o que mostra a fraqueza de suas premissas, se perde, isso se deve, ou ao fato de ter premissas ruins, ou à evidência de que nem deixando de lado os seus preceitos, para ser vitorioso, pode prová-los. Só com um amigo, como adverte La Boétie, é possível ser livre, que é o mesmo que ter uma verdadeira de discussão filosófica. Nas demais circunstâncias, o cético, por virtude, detém-se na polidez e no bom gosto. Se aparentemente perde a paciência, fá-lo como efeito da imperturbabilidade - ou seja, para assustar os outros ou por equívoco, donde precisa se desculpar.

Não pretendo ter estabelecido, não há mais razões para que seja assim do que de outro jeito, não percebo, as aparências são iguais em um caso como no outro, não há como falar mais a favor do que contra, nada parece verdadeiro que não possa parecer falso, sustento, argumento, mas não ver além e não julgo [...]. (MONTAIGNE, 1972, p. 238).

são as formas em ruibarbo dos argumentos céticos. Jamais o cético diz que não compreende, pois isso seria, além de muito rude, evidenciando a má vontade de quem escuta, entregar-se à premissas. 
"Disso resulta que, eludindo decididamente e de maneira absoluta a obrigação de se pronunciar, adiam o julgamento." Qual seria o procedimento deste filósofo na vida comum? Para respondê-lo é preciso dizer que da atividade dos céticos se desprendem sentidos indeterminados. Isso significa que o assombro produzido pelo movimento é previsível, o quando não se entrega, tal como alguém que se assusta, ainda sabendo que será assustado. A indeterminação, por isso mesmo, precisa evitar o efeito que julga poder sanar, o da crueldade intrínseca à linguagem. Neste sentido a linguagem é cruel pelo modo como participa da experiência, por sua vontade de permanecer, oras, esta é uma crueldade fundacional, e o modelo da escritura, dentre os modos de compreender os enunciados, é o que melhor nos permite perceber esse aspecto. Na crueldade enunciativa, que é a que parcialmente controlamos (uma vez que a experiência é inegociável), a da escrita é a mais intensa. Devemos, então, ligar duas pontas: a que faz uma ciência da política uma disciplina de desocultamento da crueldade, sendo assim um saber moral, com aquela do ceticismo, segundo a qual o enunciado é em si mesmo cruel, por isso se o deve evitar. Nesse sentido é que é possível empreender uma descrição moral da experiência política. A preocupação máxima com a crueldade implica, inclusive, que mostrá-la seja uma das poucas justificativas para inscrever, ou seja, fazê-lo apenas quando inevitável.

Lukács vê bem o problema quando diz que a nomeação dos objetos é um sinal do domínio sobre eles (LUKÁCS, 2010, p. 84). Por outro lado, podemos indicar que Lukács não vê a gravidade da presença da crueldade na linguagem, não o pode, em virtude do modo como naturaliza os gêneros. Na abordagem que empreende do novo - seja tomado como descoberta ou como invenção - uma "determinação ontológica essencial" é preservada, de modo que o"caso" mantém a"imediata e inseparável unidade do gênero". Para Lukács, o novo, por mais que desloque o sentido, está preso a desenvolver o gênero ao qual se atrela, como a ontogênese repete e recapitula a filogênese ${ }^{9}$ (LUKÁCS, 2010, p. 84). Quão mais o novo se especializa mais intensamente é o gênero que ele realiza, quão mais fortemente se nada, o afogamento se torna inexorável. Se interpretássemos a generidade não-mais-muda dessa forma, acabaríamos por admitir que a gratuidade do rosto humano seria o aprofundamento mesmo da desfiguração, e essa conclusão é absurda. Esta aporia deriva da, a nosso juízo equívoca, admissão da dialética fora da imagem.

9 "Isso indica uma permanência insuperável de todo exemplar na própria generidade, sempre mais independente daquilo que constitui a cada vez mais sua situação concreta, seu funcionamento concreto no interior dela etc." 
A desfiguração seria cada vez mais presente no rosto, ainda que esse se tornasse mais e mais independente, e o mesmo na relação entre o nado e o afogamento. Para Lukács é isso que pensa Marx ao dizer que o homem se emancipa nadando na práxis, e o que Hegel considera ao finalizar o homem pelo pensamento. A dialética fora da imagem - pretensamente - faria com que o conhecimento antecipasse o reconhecido ${ }^{10}$ (LUKÁCS, 2010, p. 84). A crueldade age sobre o reconhecimento, logo, nesse esquema, ela não aparece vedando o acesso ao mundo. A crueldade é grotesca, como copiosamente repetem os céticos, mas não pode ser vista se nos esforçamos para produzir efeitos dialéticos para fora da imagem. Não parece haver dialética fora da imagem senão por esse efeito de artifício. Ao mantermos a dialética dentro da imagem, a antecedência do reconhecimento ao conhecer, também tem os seus contornos aclarados. Se a dialética resta para fora da imagem, ela consome o reconhecimento, e a crueldade opera seus efeitos sem poder ser vista, ficamos sem acesso mundo, mesmo na precariedade. O novo é a crueldade. Ele só não aparece como tal se a dialética é tomada fora da imagem. Nesse contexto a relação entre o gênero (conhecimento) e a espécie (reconhecimento) deixa de ser política, donde o novo passa a ser liberado de seus deveres de moralidade, passando só a responder à interpelações, ao cometer contradições extremas. Se a dialética dorme fora da imagem, apenas o novo tem mundo e todos devem aguardar efeitos de conhecimento para ser reconhecidos. A crueldade está aí desde sempre, porque o mundo (reconhecimento) precede a inovação (conhecimento). No momento em que se quer liberar o gênero, tal consiste em apenas colocá-lo na posição de reconhecer, denominando-o com outro nome. O gênero é posto politicamente, como também o novo. Se o novo, por vezes, escava à busca de condicionantes, tal se deve a uma estratégia para fazê-lo contraditório. O ato de nomeação é cruel. A crueldade é a ausência de reconhecimento. A forma de levar a linguagem a sério, de lhe vetar as férias, é tomá-la como um vício, uma forma de estratificação que pretende escapar aos processos de responsabilização, mostrando-se vítima de inexoráveis processos históricos de contradição. Para evitarmos este caminho, é mister, como dissemos, tomar a dialética interna à imagem. Assim sendo, o novo é político, tal como o gênero: e o novo que reafirma o gênero por contradição é apenas um tipo de novo e não a novidade toda.

10 "Para poder expressar algo na linguagem, sua designação pela palavra tem de aprender essa dupla constituição real, e expressá-la: de um lado, a identidade [...], de outro, [...] sua inseparabilidade de sua própria generidade." 
Até mesmo o pôr teleológico tem natureza de instituição: a particularidade é inevitável, mesmo quando se joga o jogo da generidade.

Se dizemos que a linguagem é cruel, posto que se inscreve pela dor, isso não quereria dizer que a crueldade define o homem? Parece que não, pois isso implicaria a afirmar que não existem formas pelas quais se possa lidar com o vício da inscrição. Além disso, afirmar que há um componente político intrínseco à linguagem não é a mesma coisa que dizer que ele importa em todos os atos praticados pela linguagem. Há equilíbrios que anulam essa presença. Isso quer dizer, qualquer enunciação pressupõe a estrutura política da linguagem, mas, na maioria das situações, ela não é posta em evidência, simplesmente porque não importa. Uma outra razão para não pressupormos, ou deduzirmos, a crueldade do homem pela da escritura, deve-se ao fato de que tal implicaria a tomar o indivíduo como fonte da enunciação, quando, na verdade, ele é um dos seus produtos. A linguagem pode ser dita cruel justamente por ter natureza instituinte, mas uma vez que quem fala é um indivíduo, a linguagem se torna o único fenômeno, e não um dos modos do que define o homem. Assim, se a linguagem antecede o indivíduo, sim, este é inteiramente cruel, sem possibilidade de tergiversar, mas, felizmente, poucas são as ações que praticamos enquanto indivíduos. Uma vez que o cético evita a crueldade, ele deve claramente fugir da linguagem, ou tê-la de um modo a se apresentar também como antídoto ao vício que realiza, especialmente no que concerne ao escrito. No mais, é prudente nunca falar como indivíduo.

Sobre o que a linguagem se fixa? Sobre a experiência. Esta pode ser compreendida como um plano ontológico, branco, de pura disponibilidade. Se assim não fosse, teríamos que pensar que a linguagem é fixada sobre o indivíduo, e nada mais absurdo, porque ele a pressupõe. A linguagem é marcada sobre um plano de plena disponibilidade pictórica, tendo como uma de suas realizações aquele jogo político-jurídico denominado individualidade. Ora, o quarto vazio, a propriedade, as garantias, os direitos de ausência e retorno. Alguns dos atributos do indivíduo são mais do que compreensíveis, como aqueles que tentam estabilizar a precariedade da posse, outros, nem tanto. Não há nada de errado com o indivíduo que não a sua pretensão de monopólio sobre o acidente que constitui a singularidade. Lukács (2010, p. 94) bem nos diz que "[...] [s]em tal tendência de unificação de suas decisões práticas, nenhum ser humano, em uma sociedade razoavelmente desenvolvida, poderia alcançar qualquer tipo de vida que funcionasse". O acidente casa 
bem com a individuação, e o indivíduo, no máximo, pode ser dotado de algumas paixões mais previsíveis. Se o indivíduo é produto, a individuação é sobra. O indivíduo é a forma que antecipa certa ordem bem específica de acidentes, reprime-os ou deles faz processos. A individuação pode ser graficamente descrita pelo conjunto de inscrições acidentais causadas pela violência das paixões na experiência. Ela é o esforço da multiplicidade em se manter múltipla. A individuação nomeia uma insistência. Não há contradição entre a individuação e o indivíduo, mas também não podemos nos convencer pela ausência de conflito. O indivíduo é o instituto político pelo qual a individuação é esvaziada de si própria. Não há como dizer que haja sociedade em que alguma centelha deste processo não aconteça, da mesma forma como podemos afirmar que há aquelas em que não se completou, e, por essa razão, podem passar sem o indivíduo. A individuação desenvolve o lugar da enunciação sem precisar do indivíduo, o que este faz é proliferar elementos de sedução do enunciado, como uma troca: deixe de enunciar e siga um caminho já traçado. A individuação pode ser enfraquecida pela individualização apenas na dimensão em que a singularidade deixa de ter recepção, ela se dá, mas é soterrada. Em suma, o indivíduo precisa da individuação, mas esta pode passar sem aquele.

Pois bem, a individuação se dá em primeira e terceira pessoas. Ela está quando se vive uma experiência, distraído dos interesses estruturais do indivíduo, do Tu. A individuação está na observação do Ele, mas apenas na escuta desinteressada, na especulação a partir do que aparece, tais como a resposta à perguntas como: - Quem é ela? - Será que tem frio? etc. Se o Tu se manifesta, a individuação se esconde. Apenas o indivíduo pode ser espionado, a individuação só pode ser vista. O que queremos dizer com “a individuação está"? Que essa é a perspectiva em que se faz perceptível que não é uma obra de arte. Já o indivíduo é o império do Tu. O Eu e o Ele são indivíduos quando vistos a partir do Tu. OTu é um portador. A individuação é despertencida, tal como Hume descreve o Eu. Lukács vê problema semelhante quando escreve que a individualidade não é restrita aos grandes homens (LUKÁCS, 2010, p. 94). Apesar de ser fácil entender do que se fala quando se diz que os grandes homens possuem exacerbada individualidade, talvez esse seja um caso em que alguma ironia se faça necessária. A individualidade é o bem mais bem distribuído em sociedades medíocres e a individuação é bem distribuída em qualquer uma. Isso não quer dizer que não possa haver gênio, mas que isso não se deve aos indivíduos. Se o acidente é intrínseco, ora, ele está em todo canto, para que 
surja e possa falar - estabelecer para si um plano de enunciação por sobre o pictórico -, ser percebido, precisa que a primeira e a terceira pessoas sejam desenvolvidas. A loquacidade do Tu tende a inibir o Eu e o Ele. Pode ser que a inibição seja boa, como saber? Sim, Lukács ainda nos diz que a individualidade não decorre do desenvolvimento econômico - e é certo que ele não possui tanta clareza a respeito da imagem dialética, do indivíduo e da individuação, quanto a que aqui apresentamos -, todavia, isso não quer dizer que a associação costumeira entre individualidade e os grandes homens não decorra de causas exclusivamente econômicas (LUKÁCS, 2010, p. 117, 120-121, 125).

A individuação se isola a despeito da sociedade, a solidão dos acidentes em conjunto é inalienável. O indivíduo é diferente, ele é uma forma de estar sozinho com os outros, antecipando-os para saber como se esquivar deles. $O$ indivíduo vive no inferno do Tu, ele precisa, a todo tempo, antecipar o que se deseja dele, para poder estar sozinho. A propriedade e a autoria bem o mostram, não é pelo fato de não precisarmos pensar nelas, que não sejam atualizadas pela razão, ser proprietário é se opor ao desejo imaginado, o Tu quer, justamente, o que considero meu, na oposição e na autoria.

A vida sensata de diversas pessoas muitas vezes nasce do fato de que não são capazes de desenvolver sua personalidade em-si em um ser-para-si, mas passam a vida inteira sem saber com clareza o que realmente são e como deveriam, portanto, organizar a própria vida. Não é por acaso que um gênio como Goethe, por viver muito conscientemente, sempre teve uma posição cética e de recusa em relação ao autoconhecimento teórico, vendo na práxis o único caminho plausível para conhecer-se da maneira mais correta possível. (LUKÁCS, 2010, p. 376).

A individualidade não é a característica dos grandes homens, mas apenas daqueles escolhidos pela propriedade, a autenticidade está na individuação, nos trapos de singularidade deixados pelos acidentes, por vezes transfigurados em enunciação. Os grandes homens o são na proximidade da ação com a ontologia - com os elementos de composição da experiência -, são, portanto, homens ontológicos. Isso porque o singular está antes. O desejo do indivíduo é antecipar-se ao do outro: sempre um dilema entre inimigos. Um desejo que nunca verá a luz do dia. O indivíduo apenas seduz para induzir o Tu à fraqueza. Munidos de boas razões não assinaríamos o contrato, e, com a folha de papel em branco, veríamos as formas acidentais se reunirem, até o momento em que a enunciação se fizesse possível e a escritura que somos se tornasse, para além do inexorável, a que traçamos, 
para, então, sabermos o quão correto é nos guiar pelos melhores motivos, mas não só. Independente disso, falar, sob necessidade, depois de recusar a escritura por todos os meios, pela sensibilidade ao momento certo, é algo bom, e nesse sentido a enunciação pode ser o mutismo superado, ao invés de apenas negado com loquacidade: a necessidade mantém o silêncio na voz. É assim que precisamos compreender a enunciação: ela é uma forma de escritura. É assim que precisamos entender a escritura: enquanto superação do mutismo, é instituição. Se supera a internalização faz-se homóloga à obra.

\section{VII}

[...] na imagem do mundo de Marx domina o processo real da história. (LUKÁCS, 2010, p. 374).

Para encerrarmos é ainda preciso abordar três pontos consequentes da temática com que encerramos a última seção. A instituição precisa ser abordada pela perspectiva do átomo, da crença e da irreversibilidade. Por quê? Porque é claro que a enunciação postula sobre a experiência um objeto material - não é imperativo dizer que esta é a finalidade da generidade não-mais-muda, até porque duvidamos que haja uma -, com composição atômica, ponto de cristalização, e, por vezes, um estado de irreversibilidade. Se houvesse distinção entre idéia e matéria, então não haveria que se falar da composição da instituição. Em outras palavras, se a dialética fosse exterior à imagem, a experiência poderia ser descrita pela polaridade matéria e idéia, mas, e este é o ponto fundamental do pensamento do Lukács, com o qual é imperioso concordar, e que o faz passível de uma leitura cética, a dialética é interna às imagens. Assim, existe uma dialética na crença, mas não entre crenças. E, possivelmente, a dinâmica pela qual a crença se institui no plano pictórico a faz irreversível para a história. A crença é acrescida, não suprimida.

Algumas hipóteses sobre a história deveriam então ser aventadas: (1) a primeira, menos provável, é aquela em que nenhum construtivismo é nela percebido, ou seja, a materialidade das idéias não se inscreve na do mundo, sob elaboração intelectual. Isso quereria dizer que os homens fazem a história, mas não como querem, em nenhuma proporção. Algo é verdadeiro na noção de desígnio, não toda ela. Dessa primeira hipótese uma lição pode ser aprendida: existe uma intensa indeterminação no acréscimo de objetos ao plano da experiência, não 
havendo razão para que essa seja menor para os objetos intelectuais. Há sempre algo a se aprender com a hipótese do desígnio, até mesmo uma força trágica no acontecido: o que acontece é o que tinha que acontecer. Isso nos leva à segunda hipótese (2), um pouco mais provável, de que haja um construtivismo completo, a partir do qual objetos pictóricos podem ser acrescidos à experiência no lugar de outros, ou que podem ser suprimidos completamente etc. Nessa maneira de pensar a história existe um forte otimismo da imaginação, dentro do qual equívocos podem ser superados se aprendendo com o passado, de tal forma que a memória é a única coisa que nos avaliza, uma vez desenvolvidos os modos de suprimir um objeto ou de substitui-lo. Desta segunda hipótese podemos aderir ao fato de que há algum construtivismo e que, sim, existe alguma agência intelectual no estabelecimento de objetos pictóricos. Por certo, é o caso de rejeitar a concepção de que há plena capacidade de ação consciente sobre nossas crenças, algo do pessimismo do desígnio parece impossível de ultrapassar. (3) A hipótese que nos parece mais coerente é aquela que descreve a história de modo construtivo e arqueológico. Nesta, os vícios de um construtivismo integral são dissolvidos pela arqueologia. Dessa forma, os objetos pictóricos podem ser construídos intelectualmente, ou por vias costumeiras, mas são apenas acréscimos ao plano, e não podem ser suprimidos. O sentido, nesta abordagem, se daria na interação dos objetos no ambiente composto, no modo como interagem juntos. Uma crença antiga jamais desapareceria, mas poderia ser soterrada por crenças novas. A sobreposição de objetos não é completa em sua cobertura horizontal, existem descontinuidades e desigualdades, crenças novas podem oferecer figurações encontrando cumplicidade com crenças antigas. Aqui, algum otimismo sobre a possibilidade da mudança é admitido.

\section{Referências}

DUVE, T. Nominalisme pictural: Marcel Duchamp, la peinture et la modernité. Paris: Les Éditions de Minuit, 1984.

LUKÁCS, G. Prolegômenos para uma ontologia do ser social. São Paulo: Boitempo, 2010. Original de: Prolegomena zur ontologie des gesellschaftlichen seins.

MONTAIGNE, M. Ensaios. São Paulo: Abril Cultural, 1972.

ROUSSEAU, J. J. Do contrato social: ou princípios do Direito Político. São Paulo: Nova Cultural, 1999.

Recebido: 18 jun., 2016

Aceito: 11 jan., 2017 